\title{
GERMINAL-CELL LOSS IN NORMAL METAZOAN SPERMATOGENESIS
}

\author{
E. C. ROOSEN-RUNGE \\ Department of Biological Structure, University of Washington, \\ School of Medicine, Seattle, Washington 98195, U.S.A.
}

(Received 2nd November 1972)

\begin{abstract}
Summary. A comprehensive review of the literature, of which a representative selection is given, reveals that a loss of developing germinal cells is a feature of spermatogenesis in general. The loss may be manifested by morphological, degenerative changes in single cells or in clones of cells at various stages of development, or in atypical spermatozoa ('polymorphism of spermatozoa') usually incapable of fertilizing an egg. The degree and the modes of the cell loss are species-specific, but in general the abnormalities appear to originate during gametic mitosis and meiosis. They are associated with abnormalities in the division apparatus and the chromosomes. The hypothesis is suggested that the deviant and abortive gametes represent evidence of a mechanism of negative selection by which cells with certain undesirable characteristics are removed from the population. The nature of these characteristics is unknown at present.
\end{abstract}

\section{INTRODUGTION}

In this article, a representative selection of data from a broad survey of the literature on spermatogenesis in Metazoa is presented and critically evaluated, in order to demonstrate the important rôle which aberrations of cellular differentiation play in the process of male gametogenesis.

Degenerating cells occurring regularly at various stages in the environment of normal spermatogenesis have been described in many animals throughout the past century (e.g. Flemming, 1887; Dalcq, 1921; Roosen-Runge, 1955). In addition, abnormal or 'pathological' spermatozoa have been found in numerous species, but particularly in man (Broman, 1902; MacLeod, 1970). Many authors have considered the observations to be of great biological importance, but, nevertheless, the data have never been reviewed comprehensively and their significance is unknown. Obviously, the criteria for identification of 'degenerative cells' are of fundamental importance. Essentially, a degenerating cell is simply a dying cell. In histological preparations, cell death has been identified for a century by irregularly clumped ('pycnotic') or fragmented nuclear chromatin but in recent times, cytoplasmic features such as swelling and shrinking, vacuolization and changes in the mitochondria also have been considered as indicative of degenerative changes (for discussion, 
see Saunders \& Fallon, 1966; Roosen-Runge \& Leik, 1968). Because most of the older literature reviewed here uses the simplest possible criteria for 'degeneration' and is not concerned with subtle cell changes, it may be assumed that the diagnoses of cell death have been valid in most cases.

Another form of aberrant development of germinal cells, more obvious and somewhat better defined, is what is called 'polymorphism of spermatozoa'. The term refers to the occurrence of more than one type of spermatozoon in the same animal. One of these types is normal and capable of fertilization, while the other type or types are of abnormal morphology and presumably always unable to fertilize. Obviously, the atypical spermatozoa also represent aberrations of cellular differentiation. Cases of polymorphism are frequent in some invertebrate phyla, particularly in molluscs, annelids and arthropods, and have been reviewed by Fain-Maurel (1966). All these forms of deviant germinal cell development which occur in the normal course of spermatogenesis will be briefly reviewed, and their biological significance will be discussed.

Degenerations correlated with important regressions of the germinal epithelium such as occur seasonally, for instance, in amphibians or at a change of a testis into an ovary in molluscs will not be considered here, although the topic is undoubtedly related. There will also be no discussion of the degenerations which occur in the fetal rat testis, and in postnatal stages immediately preceding the development of differentiating spermatogonia (Roosen-Runge \& Leik, 1968; Hilscher, Hilscher, Delbrück \& Lerouge-Bénard, 1972).

\section{OBSERVATIONS}

\section{Degeneration of developing gametes}

The best known examples of this type of aberration are derived from investigations on mammals. In the rat, cell death occurs during spermatogenesis with a regularity comparable to that of mitosis (Roosen-Runge, 1955). Necrotic cells are seen at definite stages, sometimes singly, but usually in groups, and each of the 'degenerative peaks' has its morphological and quantitative characteristics. A rather large peak exists at early spermatogonial stages in the rat (Clermont, 1962) and also in the mouse (Oakberg, 1956). Another peak has been observed in the rat during the first meiotic division and still another during the time of chromatin condensation of the spermatid nucleus (RoosenRunge, 1955). In the ram, three periods during which degenerations occur have been demonstrated, (1) when spermatogonia of type A change into the intermediate type, (2) when primary spermatocytes evolve from zygotene to pachytene, and (3) during the meiotic divisions (Ortavant, 1958). Similar degenerative periods occur in the bull (Kramer, 1960), but the most detailed study on this animal (Hochereau-de Reviers, 1970) shows an additional peak among late spermatogonia. In the rabbit, the most significant cell loss appears to take place during maturation divisions (Swierstra \& Foote, 1963).

Recent advances in cell kinetics of spermatogenesis (Roosen-Runge, 1962) have made possible the quantification of degenerative cells, but much still remains to be done in this respect. In Sprague-Dawley rats, in the period between late spermatogonial and advanced spermatid stages, a cell loss of 
approximately $22 \%$ was reported (Roosen-Runge, 1955). For earlier spermatogonial stages, it appears to be even greater: one cell of type $A_{1}$ is expected to produce fifteen spermatogonia of intermediate type, but only six were found (Clermont, 1967). During meiotic divisions, the cell loss in the Sprague--Dawley rat is approximately $2 \%$ (Roosen-Runge, 1955). During the same stage, the rabbit shows a deficiency of approximately 24\% (Swierstra \& Foote, 1963). In man (fifteen normal adults), the mean ratio of spermatids to pre-diakinetic spermatocytes was $2.58(0.87$ to 3.82$)$. Compared to the theoretically expected ratio of 4.0 , this indicates a cell loss of $35 \%$ on the average (Barr, Moore \& Paulsen, 1971). In brief, there is strong evidence that cellular degenerations occur during mammalian spermatogenesis in a regular and species-specific manner. In addition to quantitative data, there are numerous purely qualitative observations which support the conclusion that cell death is part of the normal process of spermatogenesis in all mammals including marsupials (Sapsford, Rae \& Cleland, 1969).

Equally impressive are similar observations in lower vertebrates. Only a few examples will be mentioned here. In 1887, Flemming concluded from his study of cell death in the testes of Salamandra that, 'apparently there are processes of degeneration and of destruction of nuclei and cells which occur in some cysts for unknown reasons at the time of proliferation of the germinal epithelium'. Since Flemming's time, degeneration in amphibian testes has been extensively investigated (e.g. Ballowitz, 1906; Champy, 1913). In a highly pertinent paper on a reptile (garter snake), Dalcq (1921) discussed a great variety of what he called 'atypical gametes' in spermatogonial and spermatocytic stages. He became convinced that they all originated during mitotic and meiotic cell divisions, even though some were manifest in interkinetic stages. In spermatogonia, Dalcq observed mainly polycentric, but also unequal, dicentric divisions and many polynucleate cells. In spermatocytes, he found a much greater variety of abnormal types, many with giant and multiple nuclei. After considering several hypotheses on the origin of the abnormalities, he concluded that the most probable cause is an imbalance in the apparatus for the division and distribution of chromosomes, and particularly in abnormal conjugation processes during meiotic divisions, especially the second one. Dalcq assumed that all abnormal cells possessed chromosomal abnormalities. In the unknown processes which produced these, he saw devices which render certain constitutional faults of the cell lethal, which, until then, had been tolerable. The prognosis for cells inflicted with chromosomal defects is usually a rapid degeneration, but some cells may remain viable for varying lengths of time despite flaws or even deletions of whole chromosomes. Dalcq quotes the related research of Guyer (1900), who studied degenerations in the testes of hybrid pigeons and suggested that chromosomal abnormalities were induced in large part by the hybridization. When numerous casual references in the literature are added to the major accounts, there remains little doubt that degenerations occur in the testes of all vertebrates, although with varying frequency. Their association with gametic cell divisions has been established in many cases.

Similar phenomena have often been reported in invertebrates, but details 
of the degenerations have rarely been investigated. Particularly instructive are examples derived from studies of platyhelminthes (Lentati, 1970), annelids (Chatton \& Tuzet, 1943), aschelminthes (Schleip, 1912), molluscs (Thesing, 1904; Ankel, 1924; Furrow, 1935; Bulnheim, 1962) and particularly of insects (Henderson, 1907; Junker, 1923; Battaglia \& Sara, 1951; Bairati, 1967). In insects, the clonal nature of the degenerative cells is often easily seen (Henderson, 1907) because cells arising from a single spermatogonium are enclosed in a cyst and at certain stages whole cysts are degenerating. In invertebrates as in vertebrates, it has been demonstrated that degenerations may originate with mitotic or meiotic divisions and may be due to a maldistribution of chromosomal material. Tretjakoff (1905) has presented a classical example in comparing spermatogenesis in the univalent and the bivalent varieties of Ascaris megalocephala: var. univalens shows few deviations from normal spermatogenesis, but in var. bivalens, 'the apparatus of nuclear divisions functions with much less accuracy', i.e. the morphology of the chromosomes in spermatogonia and spermatocytes is conspicuously abnormal and the afflicted cells usually abort.

Considering the vast number of existing invertebrate species, there is great paucity of data, but one gains the impression that degenerative phenomena have been found wherever the spermatogenic process of a species has been thoroughly investigated. On the other hand, many more observations, particularly of a quantitative nature, are needed to determine whether all of the variety of degenerative phenomena, often casually observed, can be equated with those found in vertebrates.

\section{Polymorphism of spermatozoa}

This phenomenon, defined above, is often very conspicuous, and was observed by von Siebold in 1836 in the snail Paludina. Whenever a case of polymorphism was discovered, it was described and usually discussed in detail, and the literature on this topic confined to invertebrates is large (Fain-Maurel, 1966). Only a very few outstanding examples will be reviewed here.

Molluscs, and especially prosobranchs, display remarkable sperm polymorphism and many have been minutely investigated. Meves (1903) first established that in the snail Paludina, and also in the butterfly Pygaera, atypical spermatozoa contained an amount of chromatin which differed from the normal. He used the term 'eupyrene' for cells with a normal chromatin content, 'oligopyrene' for cells with subnormal amounts and 'apyrene' for those without chromatin. The atypical spermatozoa in Paludina are oligopyrene, and in Pygaera are apyrene. The abnormalities of atypical spermatozoa are not confined to the nucleus, but are also apparent in differences in size and general morphology, and in molluscs, in particular, in the formation of multiple flagella. Meves traced the atypical spermatids to abnormal, unequal and 'careless' meiotic divisions. The snail Valvata tricarinata offers another instructive example of sperm polymorphism (Furrow, 1935). There are four types of spermatozoa. Type $I$ is the typical flagellated cell with fertilizing capacity. Type II is a 'microspermatozoon' of one quarter the normal length with an apyrene head. Type III is a 'macrospermatozoon' with a sickle-shaped, hyperpyrene nucleus. 
This type occurs with approximately $10 \%$ of the frequency of Type I. Type IV is oligopyrene with an umbrella-shaped head. It arises in the second meiotic division and always occurs in close association with rapidly growing young oocytes whose influence seems to disturb normal spermatogenesis. Types II, III and IV are incapable of fertilizing and, in fact, Type IV degenerates within the testis. The atypical spermatozoa of the prosobranchs Scala and Janthina display 'the most peculiar morphogenetic capabilities of any known single cells' (Ankel, 1930). They are large 'sperm-carriers', many hundred micra in length. According to Ankel (1958), the atypical development begins at the stage of the spermatogonium. The infrequent atypicals are first distinguished by their large size and later differentiate by forming a wide undulating membrane and a large tail arising from the fusion of thousands of flagella, products of centriole multiplication. The cytoplasm contains yolk masses. Surprisingly, the mature cells are apyrene. Typical spermatozoa attach by the hundreds to grooves on the tail of the atypical cell and are thus transported. Several authors (e.g. Ankel, 1933; Bulnheim, 1962) have demonstrated that in related prosobranch snails, the atypical spermatozoa represent a series of differentiations evolving from minor deviations to the very rare case of the giant cell which has acquired an obvious new function although, like all other atypicals, it is incapable of fertilizing an egg.

An additional case of sperm polymorphism will be mentioned here because it offers a unique and puzzling feature. This is the case of the Pentatomidae, a family of terrestrial tropical insects, in which the atypical gametes develop exclusively in certain parts of the testis called the 'harlequin lobes' (Bowen, 1922; Schrader, 1960). The atypical forms are usually macrospermatozoa and hyperpyrene, although microspermatozoa also occur. They arise during the meiotic divisions which in the harlequin lobes are peculiarly disturbed (Schrader, 1960). The degree of the disturbance varies with the species. In some species, clumping and asynchronicity of behaviour of the bivalents may become extreme. Schrader (1960) has asked the pertinent question, 'How can so wasteful an organ as a harlequin lobe evolve?'

While the previous examples of sperm polymorphism are characterized by a great variety of atypical features in the appearance of spermatozoa, there are also cases in which only the size of the gametes seems to differ. A prime example is the polymegaly of spermatozoa observed in the Drosophila obscura species group (Beatty \& Sidhu, 1969). Three types were found (lengths $69 \mu \mathrm{m}$, $128 \mu \mathrm{m}$ and $278 \mu \mathrm{m})$ and a possible giant type $(430 \mu \mathrm{m})$. The relative frequencies of spermatozoa of each type were 'virtually constant' in each species, and the pattern of polymegaly was inheritable. As yet, there is no information on whether all size classes of spermatozoa are fertile, and it may be felt, therefore, that the case is not necessarily relevant in a review of germinal cell loss. It bears, however, great similarity to other cases of polymorphism, particularly that of the Pentatomidae.

Commonly, sperm polymorphism is regarded as confined to invertebrates, but this is a questionable restriction. For instance, several 'major' types of spermatozoa are known to occur in the semen of normal men (as well as in patients), in addition to a great variety of immature, abnormal cells which 
cannot be easily typed (MacLeod, 1970). The proportion of the major types is quite uniform in large groups of men with 'normal' spermatogenesis (for instance, macrospermatozoa $3 \%$, microspermatozoa $9 \%$, bicephalic cells $1 \%$ ). In addition, the composition of the cell population appears to show individual characteristics and to remain quite stable throughout long periods in the life of a man. There appears to be no marked difference between this phenomenon in human spermatozoa and the polymorphism of invertebrate spermatozoa, although the origin of the atypical forms is less well known in the human than in most invertebrate cases.

Human spermatogenesis offers telling examples for the gradual transition between the two phenomena of deviant development discussed above. Cells are becoming degenerative at various stages and their fate varies. They may be seen among the germinal epithelium as dead or dying cells or as cell rests. They may appear as aberrant spermatids, again often necrotic, in the lumen of the seminiferous tubules or in the semen and, finally, they may be found as still viable but atypical spermatozoa. Although specific information is not available concerning the stages at which the different abnormalities arise, there are indications that large numbers of them are due to faulty meiotic divisions (Skakkebæk, Bryant \& Philip, 1973).

\section{DISCUSSION}

The data culled from a broad survey of the literature on spermatogenesis support the view that developing gametes, individually or in clones, deviate frequently from the normal path of differentiation and, as a consequence, degenerate and abort in immature stages or mature atypically. ('Mature' is a relative term. Perhaps a spermatozoon can be said to be mature only at the moment when it penetrates the outer membrane of an egg. The definition used here docs not cover stages of maturation which occur beyond the testis, particularly in mammals.) It appears that cell loss is characteristic for the process of spermatogenesis in general, but that the degree and the mode of the loss are largely species-specific, indicating a strong genetic component in the phenomenon.

Speculation about the significance of degenerate male gametes has been concerned almost exclusively with the function of the end products. A recurrent idea has been that the remains of the degenerating cells are serving as a special nutrient for the normal gametes (Wieman, 1910; Ammann, 1954; Bairati, 1967). It is well cstablished that necrotic cells and cell rests and even spermatozoa of normal morphology may be phagocytosed by 'nurse cells', for instance by cyst cells in insects (Battaglia \& Sara, 1951; Ammann, 1954) and by Sertoli cells in mammals (Rolshoven, 1944; Roosen-Runge, 1955). It is difficult, however, to uphold the argument that degenerative products, usually present in small amounts, very much scattered or concentrated in small areas of the testis, are a general source of nutrition for the gametes. It is more reasonable to assume that, in special cascs where large amounts of necrotic cells regularly accumulate, the catabolic products may in fact be reabsorbed (Cernosvitov, 1930, 1931) and may constitute a significant contribution to the 
nutrition of germ cells, but such cases are not frequent in the animal kingdom. In a similar way, the very rare examples of viable, atypical spermatozoa which have assumed a new, specific function (such as the 'carrier-cell' in Fanthina) can hardly be adduced to prove the general usefulness of most atypical spermatozoa.

Whatever the function of the abnormal and atypical cells may be, the great majority of them disappear from the competition of fertilizing an egg long before they mature in the testis. Those which become relatively mature and viable free spermatozoa are of questionable value in fertilization. Fain-Maurel (1966), in her review of atypical spermatogenesis, stated unequivocally that 'the concept of the infertility of the atypical spermatozoa has been unanimously accepted.' This statement tends to support an absolute and probably incorrect view. Certainly an apyrene spermatozoon cannot fertilize an egg, although it may activate it (Lentati, 1970), and certainly there are at present no cases known in which oligo- or hyperpyrene atypical spermatozoa regularly fertilize. On the other hand, 'there is massive evidence from the literature that vertebrate gametes containing abnormal numbers of chromosomes are fertile', even when the variations are gross (Beatty, 1970). It seems possible that sooner or later cases of sperm polymorphism will be found in which an atypical spermatozoon is shown to be capable of fertilization. It is not probable, however, that such gametic unions would result in normal zygotes, and if they did not, the atypical condition would soon disappear in competition with the typical one. In fact, the probability of a condition of germinal cell loss ever becoming established as genetic property of a species largely rests on the fact that the degenerative cells cannot produce viable normal zygotes.

The evidence indicates that a loss of male germinal cells is an integral nonrandom part of the process of spermatogenesis. I suggest the hypothesis that this loss serves to select and remove gametes which are in some way not suitable for propagation. Some important features of this selection can be indicated. The selection begins during gametic cell divisions, mitotic and meiotic, i.e. during the diploid stage. It is associated with chromosomal abnormalities. Many major chromosome changes arise in meiosis. In fact, meiotic errors either in spermato- or in oogenesis have recently been considered one of the most important sources of known types of chromosomal aberrations (Ohno, 1970; Fechheimer, 1972). It seems that the special mechanisms of meiosis present a hurdle for cells with certain defects but, in many cases, the degenerative changes are manifest before meiosis and appear to originate in the spermatogonial divisions. Although these divisions do not seem to be as unique as the meiotic ones, they also have peculiarities which differ from somatic mitoses. As spermatogonia differentiate from one generation to the other, their divisions differentiate progressively in the direction of meiosis (Roosen-Runge, 1969). The progressive changes in morphology and size of the cells are well known (Roosen-Runge, 1962). Autoradiographic analysis has revealed that the $\mathrm{S}$ period becomes longer and the $G_{2}$ period shorter as the premeiotic divisions in mouse and rat approach meiosis, which suggests specific changes in the behaviour of DNA and other nuclear components (Monesi, 1962; Hilscher, Hilscher \& Maurer, 1969). It may be that the negative selection of certain 
cells begins in early spermatogonial divisions and may become reinforced through subsequent mitoses, reaching its decisive end with the meiotic divisions.

The genetic determination indicated by the species-specificity of the process may be very complex. In plants and in Drosophila, mutants have been found which affect the frequency of crossing-over, and segregation and non-disjunction of chromosomes in the first and second meiotic division (Fechheimer, 1972), but much less is known about genes controlling specific events during spermatogonial mitoses. The crucial lack of information about the characteristics of cells which are negatively selected leaves the field wide open to speculation.

Finally, it must be kept in mind that the degenerative phenomena, and specifically the chromosomal abnormalities, can be produced by non-genetic factors (Fechheimer, 1972). A pertinent example has been described by Meyer (1970). In Drosophila, the spermatogenic process is in part controlled by genetic factors located on the $\mathrm{Y}$ chromosome. Males partially or wholly deficient in that chromosome develop aberrant spermatids. Various rather non-specific treatments with chemicals, increased temperature and X-rays produced a large number of defective spermatids in genetically normal males, which copied the defects observed in the Y-deficient animals. But even in untreated genetically normal males, a few such phenocopies were regularly observed, as would be expected from the evidence presented in this article. The example illustrates the difficulty encountered under certain circumstances of distinguishing between effects of mutants, exogenous factors and the aberrant differentiations in normal males not subject to any known noxious influences. In animals such as the rat and the fruit fly, in which the general biology of the species and the special biology of the testis are well known, the finding of degenerative cells in spermatogenesis may be correctly diagnosed, particularly if quantitative data are available but, in most other cases, particularly in invertebrates, many of the available data will remain somewhat equivocal until exogenous factors have been excluded.

\section{AGKNOWLEDGMENTS}

This study was supported in part by USPHS grant HD-03752 from the National Institutes of Health. I thank Professor T. Mann and Dr R. A. Beatty for stimulus and advice.

\section{REFERENCES}

Ammann, H. (1954) Die postembryonale Entwicklung der weiblichen Geschlechtsorgane in der Raupe von Solenobia triquetrella R. F. R. (Lepid) mit ergänzenden Bemerkungen über die Entwicklung des männlichen Geschlectsapparates. Zool. Jb. Anat. 73, 337.

ANkel, W. E. (1924) Der Spermatozoendimorphismus bei Bythinia tentaculata L. und Viviparus viviparus L. Z. Zellforsch. mikrosk. Anat. 1, 85.

Ankel, W. E. (1930) Die atypische Spermatogenese von Janthina (Prosobranchia, Ptenoglossa). Z. Zellforsch. mikrosk. Anat. 11, 491.

ANkEL, W. E. (1933) Untersuchungen über Keimzellenbildung und Befruchtung bei Bythinia tentaculata L. II. Gibt es in der Spermatogenese von Bythinia tentaculata eine Polymegalie? Z. Zellforsch. mikrosk. Anat. 17, 160.

ANKEL, W. E. (1958) Beobachtungen und Überlegungen zur Morphogenese des atypischen Spermiums von Scala clathrus L. Zool. Anz. 160, 261.

BaIRATI, A. (1967) Struttura ed ultrastruttura dess'apparato genitale maschile di Drosophila melanogaster Meig. Z. Zellforsch. mikrosk. Anat. 76, 56. 
Ballowitz, E. (1906) Über das regelmässige Vorkommen auffällig heteromorpher Spermien im reifen Sperma des Grasfrosches, Rana muta Laur. Zool. Anz. 30, 730.

Barr, A. E., Moore, D. J. \& PAulsen, C. A. (1971) Germinal cell loss during human spermatogenesis 7. Reprod. Fert. 25, 75.

Battaglia, B. \& SARA, M. (1951) Sulla degenerazione di cellule nella spermatogenesi di alcuni insecti. Scientia genet. 4, 36.

Beatty, R. A. (1970) The genetics of the mammalian gamete. Biol. Rev. 45, 73.

Beatty, R. A. \& Sidhu, N. S. (1969) Polymegaly of spermatozoan length and its genetic control in Drosophila species. Proc. R. Soc. Edinb. B, 71, 14.

Bowen, R. H. (1922) Studies on insect spermatogenesis. IV. The phenomenon of polymegaly in the sperm cells of the family Pentatomidae. Proc. Am. Acad. Arts Sci. 57, 391.

Broman, N. (1902) Über atypische Spermien (speziell beim Menschen) und ihre mögliche Bedeutung. Anat. Anz. 21, 497.

Bulnheim, H. (1962) Elektronenmikroskopische Untersuchungen zur Feinstruktur der atypischen und typischen Spermatozoen von Opalia crenimarginata (Gastropoda, Prosobranchia). Z. Zellforsch. mikrosk. Anat. 56, 371.

Gernosvitov, L. (1930) Studien über die Spermaresorption. I. Die Samenresorption bei den Oligochäten. Zool. 7b. Anat. 52, 487.

Cernosvitov, L. (1931) Studien über die Spermaresorption. III. Die Samenresorption bei den Tricladen. Zool. Fb. Anat. 54, 295.

Gнampy, G. (1913) Récherches sur la spermatogenèse des batraciens et les éléments accessoires du testicule. Archs Zool. exp. gén. 52, 13.

Ghatton, E. \& Tuzet, O. (1943) Récherches sur la spermatogenèse du Lumbricus herculeus. Bull. Biol. Fr. Belg. 77, 29.

Crermont, Y. (1962) Quantitative analysis of spermatogenesis of the rat: a revised model for the renewal of spermatogonia. Am. F. Anat. $111,111$.

Glermont, Y. (1967) Ginétique de la spermatogenèse chez les mammifères. Archs Anat. microsc. Morph. exp. 56, Suppl. to 3-4, 7 .

Dalce, A. (1921) Etude de la spermatogenèse chez l'orvet (Anguis fragilis Linn.). Archs Biol., Paris, 31, 347.

Fain-Maurel, M.-A. (1966) Acquisitions récentes sur les spermatogenèses atypiques. Annls Biol. anim. Biochim. Biophys. 5, 513.

Fechreimer, N. S. (1972) Causal basis of chromosome abnormalities. F. Reprod. Fert. Suppl. 15, 79.

Flemming, W. (1887) Neue Beiträge zur Kenntnis der Zelle. I. Die Kerntheilung bei den Spermatocyten von Salamandra maculosa. Arch. mikrosk. Anat. Entw Mech. 29, 389.

Furrow, C. (1935) Evolution of sex in Mollusca. Trans. Ill. St. Acad. Sci. 30, 5.

Henderson, W. D. (1907) Zur Kenntnis der Spermatogenese von Dytiscus marginalis L., nebst einigen Bemerkungen über den Nucleolus. Z. wiss. Zool. 87, 644.

Hilscher, B., Hilscher, W., Delbrück, G. \& Lerouge-Bénard, B. (1972) Autoradiographische Bestimmung der S-Phasen Dauer der Gonozyten der Wistarratte durch Einfach- und Doppelmarkierung. Z. Zellforsch. mikrosk. Anat. 125, 229.

Hilscher, B., Hilscher, W. \& Maurer, W. (1969) Autoradiographische Untersuchungen über den Modus der Proliferation und Regeneration des Samenepithels der Wistarratte. Z. Zellforsch. mikrosk. Anat. 94, 593.

Hochereau-de Reviers, M. T. (1970) Etudes des divisions spermatogoniales et du renouvellement de la spermatogonie souche che $z$ le taureau. Thesis, University of Paris.

Junker, H. (1923) Cytologische Untersuchungen am den Geschlechtsorganen der halbzwittrigen Steinfliege Perla marginata (Panyer). Arch. Zellforsch. 17, 185.

KRAMER, M. F. (1960) Spermatogenesis bij de stier. Thesis, University of Utrecht.

Lentati, G. B. (1970) Gametogenesis and egg fertilization in Planarians. Int. Rev. Cytol. 27, 179.

MACLEOD, J. (1970) The significance of deviations in human sperm morphology. Adv. exp. Med. Biol. 10,481 .

Meves, F. (1903) Über oligopyrene und apyrene Spermien und ihre Entstehung nach Beobachtungen an Paludina and Pygaera. Arch. mikrosk. Anat. EntwMech. 61, 1.

Meyer, G. (1970) Phenocopies of $r$ deficiencies and extraordinary differentiation types in spermiogenesis of Drosophila. In: Comparative Spermatology, p. 347. Ed. B. Baccetti. Academic Press, New York.

Monesi, V. (1962) Autoradiographic study of DNA synthesis and the cell cycle in spermatogonia and spermatocytes of mouse testis using tritiated thymidine. F. Cell Biol. 14, 1.

OAkBeRG, E. F. (1956) A description of spermiogenesis in the mouse and its use in analysis of the cycle of the seminiferous epithelium and germ cell renewal. Am. F. Anat. 99, 391.

Онмо, S. (1970) Morphological aspects of meiosis and their genetical significance. In: Advances in Experimental Medicine and Biology, Vol. 10, The Human Testis, p. 115. Eds. Eugenia Rosemberg and G. Alvin Paulsen. Plenum Press, New York and London. 
Ortavant, R. (1958) La cycle spermatogénetique chez le bétier. Thesis, University of Paris.

Rolshoven, E. (1944) Uber Resorptionsleistungen des Sertoli-Syncytiums in den Hoden-Kanälchen. Anat. Anz. 96, 220 .

Roosen-Runge, E. G. (1955) Untersuchungen über die Degeneration samenbildender Zellen in der normaler Spermatogenese der Ratte. Z. Zellforsch. mikrosk. Anat. 41, 221.

Roosen-Runge, E. C. (1962) The process of spermatogenesis in mammals. Biol. Rev. 37, 343.

Roosen-Runge, E. G. (1969) Comparative aspects of spermatogenesis. Biol. Reprod. Suppl. 1, 24.

Roosen-Runge, E. C. \& Leik, J. (1968) Gonocyte degeneration in the postnatal male rat. Am. J. Anat. 122, 275.

Sapsford, G. S., Rae, G. A. \& Gleland, K. W. (1969) The fate of residual bodies and degenerating germ cells and the lipid cycle in Sertoli cells in the bandicoot Perameles nasuta Geoffroy (Marsupialia). Aust. F. Zool. 17, 729.

Saunders, J. W. \& Fallon, J. P. (1966) Cell death in morphogenesis. In: 25th Symp. Soc. Devl Biol. p. 289. Ed. M. Locke. Academic Press, New York and London.

Schleip, W. (1912) Das Verhalten des Chromatins bei Angiostomum (Rhabelanema) nigrovenosum. Arch Zellforsch. 7, 87.

Schrader, F. (1960) Gytological and evolutionary implications of aberrant chromosome behavior in the harlequin lobe of some Pentatomidae (Heteroptera). Chromosoma, 11, 105.

Skakkebaek, N. E., BRyant, J. I. \& Philip, J. (1973) Studies on meiotic chromosomes in infertile men and controls with normal karyotypes. 7 . Reprod. Fert. 35, 23.

Swierstra, E. E. \& Foote, R. H. (1963) Cytology and kinetics of spermatogenesis in the rabbit. $\mathcal{J}$. Reprod. Fert. 5, 309.

Thesing, C. (1904) Beiträge zur Spermatogenese der Gephalopoden. Z. wiss. Zool. 76, 94.

Tretjakoff, D. (1905) Die Spermatogenese bei Ascaris megalocephala. Arch. mikrosk. Anat. Entw Mech. 65, 383.

von Srebold, G. T. (1836) Fernere Beobachtungen über die Spermatozoen der Tiere. 2. Die Spermatozoen der Paludina vivipara. Arch. Anat. Physiol. p. 232.

Wieman, H. L. (1910) A study in the germ cells of Leptinotarsa signaticollis. 7. Morph. $21,135$. 